Plant Protection and Pathology Research

Available online at http://zjar.journals.ekb.eg

http:/www.journals.zu.edu.eg/journalDisplay.aspx?Journalld=1\&queryType=Master

\title{
EVALUATION OF NOVEL NANOPARTICLES AGAINST Tetranychus urticae AND ITS PREDATORY MITE Amblyseius gossipi
}

\author{
Mohamed S. Zayed* \\ Pest. Dept., Fac. Agri., Damietta Univ., Egypt
}

Received: 14/06/2020 ; Accepted: 21/07/2020

\begin{abstract}
The present study was carried out to evaluate the relative biological activity of six treatments. Four nanoparticles (chitosan, Hydroxyapatite, chitosan hydroxyapatite and silver hydroxyapatite), one bio-agent effective microorganisms (EMs) compared to one synthetic acricide (bifenzata) were tested against the female adults and eggs of Tetranychus urticae and its predatory mite Amblyseius gossipi using standardized method of bioassay under laboratory conditions. Effect of the tested agents on the activity of carbohydrates enzymes, total lipid and total protein content were determined. The results revealed that chitosan (NPs) showed significantly adulticidal activity against T. urticae. Furthermore, EMs was the most effective treatment on the eggs of T. urticae followed by bifenzata under laboratory conditions. Therefore, nanoparticles and EMs appeared to be highly safe and selective against Amblyseius gossipi. This study suggests the possible use of nanoparticles as safe alternatives to conventional acaricides and compatible with integrated pest management practices. They might be contribute to future applications in pest control for sustainable agriculture.
\end{abstract}

Key words: Tetranychus urticae, nanoparticles, effective microorganisms, bifenazate, Amblyseius gossipi.

\section{INTRODUCTION}

Tetranychus urticae Koch is one of the most economically important pests in a wide range of outdoor and indoor worldwide. Its control largely based on the use of conventional acaricides. However, due to its short life cycle, abundant progeny and rapidly reproduction, other considerable issues in T. urticae have been well documented to quickly develop tolerance and resistance acaricides with different modes of action (Gent, 2009).

The use of predators had proved the most effective control method for tetranychid mites and the most effective predators have been found in the family phytoseiidae (Abou-Awad and El-Banhawy, 1985). Amblyseius gossipi El-Badry (Acari Phytoseiidae), which was collected and described by El-Badry (1967), has been also of particular interest to biologists concerned with the development of integrated pest management (IPM) systems. The possibility of controlling phytophagous mites by a combination of biological and chemical methods had proved a less costly and more permanent method of control than chemical pesticides alone (Hislop and Porkopy, 1981).

Acaricides in many cases of resistance have been reported, resulting in failure to effectively control pest populations (Feyereisen, 2012; Zhu et al., 2014). In order to delay the development of resistance, research is needed to develop better systems for pest control. Acaricides including bifenazate is widely used to control the twospotted spider mite. However, bifenazate is one of the most frequently used acaricides to control spider mites which has a potent biological activity against $T$. urticae. Consequently, repeated extensive use of bifenazate against T. urticae populations has led to control failures in many areas due to the high $T$. urticae reproductive potential, haplo-diploid sexual reproduction and short life cycle that facilitate the rapid development of resistance to these

\footnotetext{
*Corresponding author: Tel. : +201022000389

E-mail address: mohamedsalem01022000389@gmail.com
} 
acaricides (Piraneo, 2013). Indicating that a strategy to control resistance should be developed using different modes of acaricidal action on the pest (Chen et al., 2019).

Effective microorganism (EMs) technology is reported to support sustainable practices in farming, improve composting operations and reduce environmental pollution. Available studies which have used scientific methods to investigate these additives showed that although long-term beneficial effects are not proven, they gave satisfied results in insect control as reported by Younis et al. (2007) as well as Muthusamy and Jayabalan (2011).

The use of nanoparticles (NPs) as pesticides is just emerging. Thus, it important to identify potential risk management issues and discuss unique challenges associated with the use of nanotechnology in pest control (Rouhanil et al., 2008; Stone et al., 2010; Debnath, 2012). Chitosan (Ch) and chitosan metal-complex nanoparticles (NPs) can be used as sustainable biopesticide in pest control (Badawy and ElAswad, 2012). Chitosan obtained from the alkaline deacetylation of chitin (Riccardo et al., 1998). These nanoparticles possess several valuable structural and functional properties, including biocompatibility, biodegradability, low toxicity, and good miscibility with other polymers, and also has a highly chemically reactive structure (Kubota and Equchi, 1997) and biological activity (Rabea et al., 2003; Gerasimenko et al., 2004; Badawy, 2008 and 2010). Ch- NPs may serve as a good alternative as broad-spectrum and highly persistent pesticides due to their non-toxic effects to vertebrates and humans, biodegradability, and their insecticidal and microbicidal properties (Rabea et al., 2003; Badawy et al., 2005).

This study aimed to investigate the acaricidal and ovicidal activity of the nanoparticle agents (chitosan, Hydroxyapatite, chitosan hydroxyapatite and silver hydroxyapatite) and effective bioagent (EMs) against $T$. urticae and the predator Amblyseius gossipi. Effects of the tested agents on the activity of carbohydrates enzymes, total protein and total lipid were determined to elucidate the biochemical effects of the tested materials against $T$. urticae.

\section{MATERIALS AND METHODS}

\section{Tested Mites}

T. urticae reared according to Dittrich (1962). $T$. urticae colonies were obtained from castor bean plants from Damietta Governorate, Egypt and reared under laboratory conditions at $25 \pm$ $2^{\circ} \mathrm{C}$ under 16:8 (light : dark) photoperiod to encourage plant growth, and $70 \pm 5 \mathrm{RH}$ Amblyseius gossipi (El-Badry) was reared on pollen grains of castor oil (Ricinus communis) plants as described by Overmeer et al. (1982). The culture was kept under the same conditions of temperature, humidity and photoperiod as $T$. urticae culture. A brush (No.0) was used in transferring mites from plant to another.

\section{Tested Agents}

Chitosan nanoparticles (Ch-NPs), with purity of $99.99 \%$ and a size of $100 \mathrm{~nm}$, degree of deacetylation (DDA 89\%) and molecular weight $\left(892.27 \times 10^{5}\right) \mathrm{g} / \mathrm{mol}$. Hydroxyapatite nanoparticles (Ha-NPs) with purity of $99.99 \%$ and a size of $100 \mathrm{~nm}$. Chitosan hydroxyapatite nanoparticles (Ch. Ha-NPs) with purity of $99.99 \%$ and a size of $80 \mathrm{~nm}$. Silver hydroxyapatite nanoparticles (S. Ha NPs) with purity of $99.99 \%$ and a size of $50 \mathrm{~nm}$. All nanoparticles were obtained from Egypt Nanotech Company limited, El-Wahaat Road, $6^{\text {th }}$ October, Cairo, Egypt. Bio-control agent: Effective microorganisms (EMs) used in this study were obtained from the Ministry of Agriculture, Cairo, Egypt. This formulation contained 60 species of beneficial microorganisms grow in special media and produced locally under supervision of the Japanese EMRO Scientific Organization. Bifenzata (acramite 40\% EC) was produced by BAYER company EL-Doki, Cairo, Egypt.

\section{Adulticidal Activity of the Tested Agents Against T. urticae}

To evaluate the toxicity of the tested chemicals to the two-spotted spider mite T. urticae, the leaf disc dip technique was used according to Siegler (1947). A series of concentrations (ppm) were prepared according to the active ingredient of each agent. Distilled water was used in all dilutions. Four discs of castor bean leaves were dipped in each concentration for 5 seconds and left to dry. Then 10 adult female mites were 
transferred to each disc. The discs were placed on moist filter paper, which rested on moist cotton wool pad contained in Petri dishes and kept in the same condition of breeding room. Mortality counted and corrected using Abbott's Formula (Abbott, 1925).

\section{Ovicidal Activity of the Tested Agents Against T. urticae eggs}

Ten adult females of $T$. urticae were placed on a clean castor bean leaf disc upon a water soaked cotton wool pad in petri dish. Sufficient discs were set up to provide enough eggs for experiments. The adult females were allowed to oviposite overnight and then were removed. T. urticae eggs were less than 24 hours old at the start of an experiment. This ensured that they would not hatch during the experimental period according to Burnett (1971) and Giboney (1981).

\section{Adulticidal Activity of the Tested Agents Against $A$. gossipi}

Leaf disc dip technique was used to measure toxicity of the tested agents against $A$. gossipi. Five adult females were transferred to each disc. The discs were placed on moist filter paper, which rested on moist cotton wool pad in Petri dishes and kept in the same conditions of breeding room. Mortality were counted and corrected using Abbot's formula (Abbott, 1925).

\section{Enzyme Assay}

The homogenate of the two spotted spider mite adults of treated with the tested treatments was prepared after being starved for 6 hours. Each sample was ground in mortar to obtain fine powder, suspended were homogenized in an ice solution of $0.25 \mathrm{M}$ sucrose using a glass homogenizer and centrifuged at 3.000 RPM according to El-Doksh (2001). The supernatants were used to determine carbohydrate enzyme activities (amylase, trehalose and invertase), total protein and total lipid according to the method described by Ishaaya and Swirski (1976), Schmit (1964) and Henry (1964), respectively.

\section{Statistical Analysis}

Abbott's formula was used to correct (\%) mortality according to natural mortality.

Mortality $(\%)=[$ Mortality $(\%)$ of treatment mortality (\%) of control $\div 100$ - Mortality $(\%)$ of control] $\times 100$ (Abbott, 1925)

The toxicity lines were statistically analyzed according to Litchfield and Wilcoxon (1949).

Selectivity ratio of tested compounds on predator mites $A$. gossipi was determined as follow according to Wilkonson (1976):

Selectivity ratio $(\mathrm{SR})=\mathrm{LC}_{50}$ of the compound on predator $\div \mathrm{LC}_{50}$ of the compound on prey

Selectivity index $=$ SR of compound on predator $\div$ SR of the most selective compound (compound of the highest SR value) $\times 100$

Toxicity index of the tested compounds was determined according to Sun (1950) as follows:

Toxicity index $=\mathrm{LC}_{50}$ of the most effective compound $\div \mathrm{LC}_{50}$ of the tested compound $\times 100$

Safety index of the tested compounds on predator mite was determined according to Aref (1997) as follows:

Safety index $=\mathrm{LC}_{50}$ of tested compound on predator $\div \mathrm{LC}_{50}$ of the least effective compound on predator $\times 100$

Statistical analysis of all data was carried out according to ANOVA and Duncan's multiple range test (Duncan 1955).

\section{RESULTS AND DISSCUSSION}

\section{Adulticidal Activity of the Tested Agents Against T. urticae}

Concerning $\mathrm{LC}_{50}$ level, results in Table 1 indicate that Ch-NPs was the most efficient treatment followed by EMs, Ha-NPs and Bi with $\mathrm{LC}_{50}$ values of 47.6, 51.28, 70.97 and 104.38 ppm, respectively. While, Ch. Ha-NPs had a moderate toxicity with $\mathrm{LC}_{50}$ value of 120.95 ppm. S. Ha-NPs showed the lowest acaricidal activity with $\mathrm{LC}_{50}$ value of $126.81 \mathrm{ppm}$. 
Mohamed S. Zayed

Table 1. Adulticidal activity of the tested agents against $T$. urticae

\begin{tabular}{lcccccc}
\hline Compound & LC $_{50}(\mathbf{p p m})$ & \multicolumn{2}{c}{ Confidence limit } & \multirow{2}{*}{$\begin{array}{c}\text { Potency } \\
\text { levels }\end{array}$} & $\begin{array}{c}\text { Slope } \\
\text { value }\end{array}$ & $\begin{array}{c}\text { Toxicity } \\
\text { index }\end{array}$ \\
\cline { 3 - 5 } & & Lower & Upper & & & \\
\hline Ch- NPs & 47.67 & 42.49 & 51.90 & 2.67 & 3.03 & 100 \\
Ha- NPs & 120.95 & 116.01 & 125.42 & 1.04 & 6.31 & 39.41 \\
Ch. Ha- NPs & 70.97 & 62.24 & 77.30 & 1.79 & 2.93 & 67.17 \\
S. Ha-NPs & 126.81 & 109.35 & 140.34 & 1.00 & 5.88 & 37.60 \\
EMs & 51.28 & 43.17 & 58.04 & 2.47 & 2.34 & 92.97 \\
Bi & 104.38 & 96.91 & 115.44 & 1.21 & 4.33 & 45.67
\end{tabular}

Chitosan (Ch-NPs); Hydroxyapatite (Ha-NPs); chitosan hydroxyapatites)Ch. Ha-NPs); Silver hydroxyapatite( S. Ha-NPs); Effective microorganisms (EMs); Bifenzazate (Bi).

The obtained results are in agreement with the results of Campos et al. (2015) who reported that chitosan nanoparticle sustainable bio pesticide of pest control that presented acaricidal activity against $T$. urticae. In addition, repellent activity and reduction in oviposition were observed for the mites. Obtained results are on line with those obtained by Zayed, (2016) who illustrated that EMs were the most toxic treatment against $T$. urticae followed by ethoxylated fatty acids amides (EFAA), silica bulk, silica NPs, zinc oxide NPs, profenofos, emmactin benzoate and salicylic acid. Chitosan nanoparticles were effective in control of $T$. urticae, presenting both repellent 1.14 fold and acaricidal activity 2.2 fold in both cases with a six-fold higher inhibition of oviposition after 72 hours for mites treated with the nanoparticles, compared to those treated with the emulsion (Campos et al., 2015).

Jalalizand et al. (2013) reported that leaf dipping bioassay showed significant mortality by silver nanoparticles against adult mites showed different effects on T. urtice which is based on increase in concentration. Derbala et al. (2014) Found that zinc oxide nanoparticles was the most effective treatment against the newly hatched larvae of pink bollworm followed by spinosad, EMs, silica and pyriproxyfen with $\mathrm{LC}_{50}$ values of $11.29,15.17,20.57,37.78$ and 86.78, respectively. The high efficacy of nanoparticles against $T$. urticae may be due to the absorbance of nanoparticles into the cubicula lipids of the mite, resulting in damage in the protective wax layer (made of various fatty acids and lipids that act as an effective barrier to water loss) and induces death by desiccation (Rahman et al., 2009).

\section{Ovicidal Activity of the Tested Agents Against T. urticae Eggs}

The obtained results in Table 2 indicate that $\mathrm{EM}_{\mathrm{S}}$ was the most efficient treatment against eggs of $T$. urticae with $\mathrm{LC}_{50}$ value of 9.96 followed by Bi, Ch-NPs, Ha-NPs and Ch. HaNPs with $\mathrm{LC}_{50}$ values of $19.93,32.76,41.62$ and $52.85 \mathrm{ppm}$, respectively. While, S. Ha- NPs showed the lowest toxicity among all tested compounds with $\mathrm{LC}_{50}$ value of $83.80 \mathrm{ppm}$.

EMs showed a key affect against eggs of T. urticae and this may be due to the presence of several microbial isolates in the formulation that have entomopathogenic activity through production of some toxic secondary metabolites (Siegel $\boldsymbol{e t}$ al., 1990).

Effective microorganisms (EMs) are a combination of various useful microbes which are efficient in insect control due to its ability to create esterases compounds, defense enzymes and secrete hydrolyses acid (Kyan, 1999; Xu et al., 2000; Diver, 2001; Khaliq et al., 2006; Ndona, 2008; Filipp et al., 2009; Zayed, 2016). A key advantage of biological agents relative to chemical pesticides is their capacity to kill pests (functional response) and to reproduce in pest (numerical response) thereby, giving some control in future pest generations (Derbalah $\boldsymbol{e t}$ al., 2014). 
Zagazig J. Agric. Res., Vol. 47 No. (4) 2020

Table 2. Ovicidal activity of the tested agents against $T$. urticae eggs

\begin{tabular}{lcccccc}
\hline Compound & LC $_{\mathbf{5 0}}(\mathbf{p p m})$ & \multicolumn{2}{c}{ Confidence limit } & \multirow{2}{*}{$\begin{array}{c}\text { Potency } \\
\text { levels }\end{array}$} & $\begin{array}{c}\text { Slope } \\
\text { value }\end{array}$ & $\begin{array}{c}\text { Toxicity } \\
\text { index }\end{array}$ \\
\cline { 3 - 5 } & & Lower & Upper & & & \\
\hline Ch- NPs & 32.76 & 21.89 & 44.42 & 2.56 & 2.91 & 30.40 \\
Ha- NPs & 52.85 & 39.45 & 62.34 & 1.59 & 1.86 & 18.85 \\
Ch. Ha-NPs & 41.62 & 30.09 & 49.95 & 2.01 & 1.55 & 23.93 \\
S. Ha-NPs & 83.80 & 71.76 & 112.19 & 1.00 & 2.47 & 11.88 \\
EMs & 9.96 & 5.01 & 14.24 & 8.41 & 0.81 & 100.00 \\
Bi & 19.93 & 10.02 & 28.48 & 4.02 & 0.82 & 49.97
\end{tabular}

Chitosan (Ch-NPs); Hydroxyapatite (Ha-NPs); chitosan hydroxyapatites (Ch. Ha-NPs); Silver hydroxyapatite (S. Ha-NPs); Effective microorgainsms (EMs); Bifenzazate (Bi).

\section{Adulticidal Activity of the Tested Agents Against $A$. gossipi}

The results in Table 3 show that Bi was the most effective compound on adult females of predatory mite $A$. gossipi with $\mathrm{LC}_{50}$ of 18.75 ppm, followed by S.Ha-NPs and Ch. Ha-NPs with $\mathrm{LC}_{50}$ values of 43.09 and $45.50 \mathrm{ppm}$, respectively. Ch-NPs and Ha- NPs showed a moderate toxic effects with $\mathrm{LC}_{50}$ of 70.71 and $60.12 \mathrm{ppm}$ respectively, while EMs formulation was the least toxic agent to adult females of A. gossipi with $\mathrm{LC}_{50}$ value of $153.32 \mathrm{ppm}$.

Referring to the toxicity index (T. index) at $\mathrm{LC}_{50}$ level, the results in Table 3 confirm that $\mathrm{Bi}$ was the most toxic compound to adult females of A. gossipi with toxicity index of 100, followed by S.Ha-NPs, Ch. Ha-NPs, Ha-NPs and Ch- NPs with toxicity indexes of 43.51, 41.20, 31.19 and 26.51, respectively, while EMs was the least toxic compound to adult females of A. gossipi with toxicity index of 12.23.

The safety index (Aref, 1997) is a value for the tested compound on predatory mite or indicted by comparing $\mathrm{LC}_{50}$ values of the compound against the predator with that of the least effective one. The safety index, selectivity index and selectivity ratio values in Table 3 showed that bio formulation (EMs) was the most safe compound to adults of predatory mite A. gossipi. Bi was of the least safety on adult predatory mite A. gossipi. These results confirmed that EMs appeared to be of high selective on predatory mite $A$. gossipi. The selectivity index is considered the most precise value that indicates how far the compounds behave toward the two adult species of mites (predator and phytophagous one). In other words, the safest compound against the predator and the same time the most toxic to the prey mite is the most suitable compound that must be advised to be involved in an integrated pest management. It is interesting to find out that EMs has the highest of selectivity and safety index, that gives them ability to be used in IPM programs.

The present results are accessional in agreement with El-Beheiry et al. (1987) who found that the tested mineral oil was appeared has high safety index that means low toxicity against the predatory mite. This is an advantage required for IPM parallel to cypermethrin $(10 \%$ EC) which has less toxic effect than Lannate (90\% WP) to predatory mite $A$. gossipi. Osman (1997) showed that mineral oils (Shokrona and Shokrona Super) were of little adverse effect on predacious mite A. gossipi comparing with synthetic acaricides.

\section{Biochemical Responses}

The results showed that the highest reduction in trehalose activity was in the adult females of T. urticae treated with $\mathrm{Bi}$ with value of 108.26 followed by EMs, S.Ha -NPs and Ha- NPs with values of $154.57,166.64$ and $186.54 \mu / \mathrm{L}$, respectively. While $\mathrm{Ch}$. NPs and Ch. Ha-NPs increased trehalose activity with values of 239.54 
Table 3. Adulticidal activity and toxicity parameters of the tested agents against $\boldsymbol{A}$. gossipi

\begin{tabular}{lccccccccc}
\hline Compound & $\begin{array}{c}\text { LC } \\
(\mathbf{5 0 m})\end{array}$ & \multicolumn{2}{c}{$\begin{array}{c}\text { Confidence } \\
\text { limit }\end{array}$} & $\begin{array}{c}\text { Potency } \\
\text { levels }\end{array}$ & $\begin{array}{c}\text { Slope } \\
\text { value }\end{array}$ & T. index & S. index & (S.R) & $\begin{array}{c}\text { Selectivity } \\
\text { index }\end{array}$ \\
\cline { 3 - 9 } & & Lower & Upper & & & & & & \\
\hline Ch- NPs & 70.71 & 49.57 & 84.74 & 2.17 & 1.56 & 26.51 & 46.11 & 1.48 & 49.50 \\
Ha- NPs & 60.12 & 47.05 & 70.09 & 2.56 & 1.74 & 31.19 & 39.12 & 0.50 & 16.72 \\
Ch. Ha- NPs & 45.50 & 29.35 & 58.65 & 3.37 & 1.10 & 41.20 & 29.68 & 0.64 & 21.14 \\
S.Ha-NPs & 43.09 & 27.06 & 58.10 & 3.56 & 0.88 & 43.51 & 28.10 & 0.34 & 11.37 \\
EMs & 153.32 & 126.85 & 195.96 & 1.00 & 1.87 & 12.23 & 100.00 & 2.99 & 100.00 \\
Bi & 18.75 & 11.30 & 25.09 & 8.18 & 0.87 & 100.00 & 12.22 & 0.18 & 6.02 \\
\hline
\end{tabular}

Chitosan (Ch-NPs); Hydroxyapatite (Ha-NPs); chitosan hydroxyapatites (Ch. Ha-NPs); Silver hydroxyapatite(S. Ha-NPs); Effective microorganisms (EMs); Bifenzazate (Bi). Safety index (S. Index) was calculated with respect to wormseed extract the least effective compound. Selectivity index (S. Index) was calculated with respect to EMS as the most selective compound.

Table 4. Effect of the tested agents on carbohydrate enzymes, total protein and total lipid in adult females of $T$. urticae treated with $\mathrm{LC}_{50}$ values of the tested agents

\begin{tabular}{lccccc}
\hline Compound & \multicolumn{3}{c}{ Carbohydrate enzymes } & Total protein & Total lipid \\
\cline { 2 - 4 } & $\begin{array}{ccccc}\text { Trehalose } \\
(\boldsymbol{\mu} / \mathbf{L})\end{array}$ & $\begin{array}{c}\text { Amylase } \\
(\boldsymbol{\mu} / \mathbf{L})\end{array}$ & $\begin{array}{c}\text { Invertase } \\
(\boldsymbol{\mu} / \mathbf{L})\end{array}$ & $\mathbf{g} / \mathbf{L}$ & $\mathbf{g} / \mathbf{L}$ \\
\hline Ch- NPs & $239.54^{\mathrm{a}}$ & $21.75^{\mathrm{a}}$ & $114.55^{\mathrm{a}}$ & $3.847^{\mathrm{a}}$ & $2.790^{\mathrm{d}}$ \\
Ha- NPs & $186.54^{\mathrm{d}}$ & $12.71^{\mathrm{e}}$ & $82.16^{\mathrm{c}}$ & $2.227^{\mathrm{d}}$ & $3.113^{\mathrm{e}}$ \\
Ch. Ha-NPs & $214.13^{\mathrm{b}}$ & $19.51^{\mathrm{b}}$ & $101.45^{\mathrm{b}}$ & $2.943^{\mathrm{b}}$ & $2.973^{\mathrm{f}}$ \\
S.Ha-NPs & $166.64^{\mathrm{e}}$ & $14.86^{\mathrm{d}}$ & $66.21^{\mathrm{d}}$ & $2.513^{\mathrm{c}}$ & $3.623^{\mathrm{d}}$ \\
EMs & $154.57^{\mathrm{f}}$ & $16.92^{\mathrm{c}}$ & $81.28^{\mathrm{c}}$ & $3.761^{\mathrm{a}}$ & $3.950^{\mathrm{c}}$ \\
Bi & $108.26^{\mathrm{g}}$ & $10.69^{\mathrm{f}}$ & $68.03^{\mathrm{d}}$ & $1.990^{\mathrm{e}}$ & $4.173^{\mathrm{b}}$ \\
Control & $198.34^{\mathrm{c}}$ & $16.65^{\mathrm{c}}$ & $100.50^{\mathrm{b}}$ & $3.877^{\mathrm{a}}$ & $4.833^{\mathrm{a}}$ \\
LSD & 7.378 & 0.901 & 3.248 & 0.154 & 0.120
\end{tabular}

Chitosan (Ch-NPs); Hydroxyapatite (Ha-NPs); chitosan hydroxyapatites)Ch. Ha-NPs); Silver hydroxyapatite (S.Ha-NPs); Effective microorganisms (EMs); Bifenzazate (Bi)

and $214.13 \mu / \mathrm{L}$, respectively. Similar results were found in amylase activity, therefore, the highest reduction in amylase activity was in the adults female of $T$. urticae treated with $\mathrm{Bi}$ with value of 10.69 followed by Ha-NPs and S.Ha-NPs with values of $12.71,14.86 \mu / \mathrm{L}$ respectively. On contrast, EMs had no significant effect on amylase activity. It seems that amylase activity was non target for EMs that recorded 16.92 respects to control $16.65 \mu / \mathrm{L}$.
On the other hand, the activity of amylase enzyme was increased in treatment with $\mathrm{Ch}$ NPs and Ch. Ha-NPs with values of 21.75 and $19.51 \mu / \mathrm{L}$, respectively. For invertase activity, the results showed the highest reduction by treatment with value of S.Ha-NPs with value of $66.21 \mu / \mathrm{L}$ followed by Bi, EMs, Ha-NPs, with values of $68.03,81.21,82.16 \mu / \mathrm{L}$, respectively. However, for Ch-NPs and Ch. Ha-NPs the enzyme activity of invertase was highly increased relative to control with values of 
114.55 and $101.45 \mu / \mathrm{L}$, respectively. in briefly, chitosan and its derivatives increased the activity of carbohydrate hydrolyzing enzymes. The reduction of carbohydrate hydrolyzing enzymes activities could be result from a chain effect originating primarily from inhibition of chitin synthesis (Salem et al., 1995).

Bifenazate reduced the activity of carbohydrate hydrolyzing enzymes. Although first thought bifenazate a neurotoxin, genetic evidence has pointed towards a mitochondrial target site, bifenazate can act as a synergist or allosteric modulator of functionally expressed $T$. urticae (Nieuwenhuyse et al., 2012). The results implied that the tested materials disrupted the carbohydrate hydrolyzing enzymes accordance with the toxicity data. The observed changes in levels of the tested enzymes may be due to the physiological or pathological alterations induced by treatments and may significantly contribute to their levels in treated larvae (Gupta et al., 1985). The obtained results are in agreement with Derbalah et al. (2014) who showed the highest reduction in amylase activity, slightly reduction in trehalose activity and increased invertase activity by treatment with EMs in $4^{\text {th }}$ instar larvae of pink bollworm.

Concerning data in Table 4, all treatments reduced total lipids and total protein contents compare with control. The highest reduction in total protein content was significantly recorded by bifenazate followed by Ha- NPs, S. Ha- NPs and $\mathrm{Ch}$. Ha-NPs with values of 1.990 then $2.227,2.513$ and $2.943 \mathrm{~g} / \mathrm{L}$, respectively. ChNPs and EMs had no significant effects on total protein content. For total lipid, all treatments significantly reduced total lipid content relative to control. Chitosan (NPs) was the highest in reduction followed by Ch. Ha-NPs, Ha- NPs, S.Ha-NPs, EMs and Bi with values of 2.790, $2.973,3.113,3.623,3.950$ and $4.173 \mathrm{~g} / \mathrm{L}$, respectively.

The present study showed that the tested materials reduced the total protein which is in agreement with results of Zayed (2016) who found that the total protein content decreased in $4^{\text {th }}$ instar larvae of spiny bollworm Earias insulana treated with silica, zinc oxide nanoparticle and EMs. Protein content is one of the indicators of larval health, rather than a biomarker of larval defense or immune competence (Zhang et al., 2011). Proteins are among most important compound of insects that bind with foreign compounds. The increase in the total protein of treated larvae may reflect the increase in the activity of enzymes. The obtained results are in agreement with those obtained by Wigglesworth, (1959); Gunning $e t$ al. (1997) and Salgado, 1997).

\section{Conclusion}

The aim of this work was to investigate the importance of using nanoparticles (chitosan and its derivatives) and EMs as biologically active agents against $T$. urticae. These agents showed to have the potential as alternatives for $T$. urticae control instead of some harmful conventional acaricides. In addition, they may be introducing a highly acaricidal activity and a great selectivity compared to bifenazate.

\section{REFERENCES}

Abbott, W.S. (1925). A method for computing the effectiveness of an insecticide. J. Econ. Entomol., 18: 265-267.

Abou-Awad, B.A. and E.M. El-Banhawy (1985). Comparison between the toxicity of synthetic pyrethroids and other compounds to the predacious mite Amblyseius gossipi (Mesostigmata: Phytoseiidae). Exp. Appl. Acarol., (1): 185- 191.

Aref, S.A. (1997). Integrated control of some economic pest cotton fields. M. Sc. Thesis, Fac. Agric. Kafr El-Sheikh, Tanta Univ.

Badawy, M.E.I. (2008). Chemical modification of chitosan: Synthesis and biological activity of new heterocyclic chitosan derivatives. J. Polymer Int., 57 (8): 254-261.

Badawy, M.E.I. (2010). Structure and antimicrobial activity relationship of quaternary $\mathrm{N}$-alkyl chitosan derivatives against some plant pathogens. J. Appl. Polymer Sci., 117 (10): 960-969.

Badawy, M.E.I., E.I. Rabea, T.M. Rogge, C.V. Stevens, W. Steurbaut, M. Höfte and G. Smagghe (2005). Fungicidal and insecticidal activity of $O$-acyl chitosan derivatives. J. Polymer Bulletin, 54 (11): 279-289.

Badawy, M.E.I. and A.F. El-Aswad (2012). Insecticidal activity of chitosans of different 
molecular weights and chitosan-metal complexes against cotton leafworm Spodoptera littoralis and oleander aphid Aphis nerii, Plant Protect. Sci., 48 (3): 131141.

Burnett, T. (1971). Prey consumption in Acarina predator- prey populations read in the greenhouse. Can. J. Zool., 49 : 903.

Campos, E.V.R., J.L. de Oliveira, L.F. Fraceto and B. Singh (2015). Polysaccharides as safer release systems for agrochemicals. J. Agron. Sustain. Dev., 35(19): 47-66.

Chen, J.C., Y.J. Gong, P. Shi, Z.H. Wang, L.J. Cao, P. Wang and S.J. Wei (2019). Fieldevolved resistance and cross-resistance of the two-spotted spider mite, Tetranychus urticae, to bifenazate, cyenopyrafen and SYP-9625. J. Appl. Acarol., 77 (19): 545-554.

Debnath, N. (2012). Study on entomologic efficacy of silica nanoparticles in comparison with other oxide nanoparticles: Value addition to these silica nanoparticles, Ph.D. Thesis, Biol.1 Sci. West Bengal Univ. Technol. India Chapter Three 41-70.

Derbalah, A.S., A.A. Khidr, H.Z. Moustafa and A. Taman (2014). Laboratory evaluation of some non conventional pest control agents against the pink bollworm Pectinophora gossypiella. J. Biol. Pest Control, 24 (5): 363-368.

Dittrich, V. (1962). A comparative study of toxicological test methods on a population of the two-spotted spider mite (T. urticae). J. Econ. Entomol., 55 (5) 644- 648.

Diver, S. (2001). Nature Farming and Effective Microorganisms', Rhizosphere II: Publications. From Steve Diver Link http://ncatark.uark. edu/- steved/Nature-Farm-EM.html.

Duncan, D.B. (1955). Multiple Ranges and Multiple F. Test. Biomet. J., 11: 1-42.

El-Badry, E.A. (1967). Five new phytoseiid mites from U. R.A., with collection notes on three species (Acarina :Phytoseiidae). Indian, J. Entomol., 29 (7):177-184pp.

El-Beheiry, M.M., A. A. Hassan and F. M. Hoda (1987). The relationships between diet, biological aspects and susceptibility to different pesticides of the predatory mite Amblyseius gossipi (El-Badry). J. Agric. Res. Tanta Univ., 13 (4); 1177- 1184.

El-Doksh, R.A. (2001). Toxicological studies on some agricultural pests. Ph.D. Thesis, Fac. Agric., Kafr El-Sheikh, Tanta Univ., 217.

Feyereisen, R. (2012). Insect CYP genes and P450 enzymes in Insect molecular biology and Biochemistry (ed. Gilbert L. I), J. Elsevier, Ch., 8: 236-316

Filipp, M., A. Spornberger, H. Keppel and R. Brunmayer (2009). Influence of effective microorganisms (EM) on yield and quality in organic apple production. Univ. Nat. Res. and Appl. Life Sci. J. Crop Prod., Rev. Papers, 281-284.

Gent, D.H. (2009). Field Guide for Integrated Pest Management in Hops. $1^{\text {st }}$ Ed. Oregon State Univ., Univ. Idaho, USDA Agricultural Res. Service, and Washington State Univ.

Gerasimenko, D.V., I.D. Avdienko, G.E. Bannikova, O.Y. Zueva, V.P. Varlamov (2004). Antibacterial effects of water soluble low molecular weight chitosan. Appl. Biochem. Microbiol., 40: 253-257.

Giboney, F. (1981). A laboratory evaluation on Amblyseius fallacis (Garman) (Acarina: Phytoseiidae) as a control agent for tetranychid mites. Ph.D. Thesis, UCNW. Bangor.

Gunning, R.V., G.D. Moores and A.L. Devonshire (1997). Esterases and fenvalerate resistance in a field population of Helicoverpa punctigera (Lepidoptera: Noctuidae) in Australia. Pest. Biochem. Physiol., 58: 155-162.

Gupta, R.C., J.K. Malik and G.S. Paul (1985). Acute Toxicity Study: Fenitrothion induced biochemical changes In Male' Rats. Pharmac, 13: 173-184.

Henry, R.J. (1964). Colorimetric method of total proteins. Clinical Chemistry, Harper and Row Publishers, New York, 181.

Hislop, R.G. and R.J. Porkopy (1981). Influence of pesticides on the predator Amblyseius fallacis (Acarina: Phytoseiidae) under laboratory and field conditions. Prof. Ecol., 3: 157-172. 
Ishaaya, I. and E. Swirski (1976). Trehalase, Invertase and amylase activities in the black scale, Saissetia oleae and their relation to host adaptability. J. Insect Physiol., 22:10251029.

Jalalizand, A., S. Gavanji, J.K. Esfahani, M.H. Besharatnejad, M.S. Emami and B. Larki (2013). The effect of Silver nanoparticles on Tetranychus urticae, Int. J. Agric. and Crop Sci., 5 (8): 820-827.

Khaliq, M., K. Abbasi and T. Husain (2006). Effects of integrated use of organic and inorganic nutrient sources with effective microorganisms (EMs) on seed cotton yield in Pak. Bio resource Tech. 97: 967-972.

Kubota, N. and Y. Equchi (1997). Facile preparation of water-soluble $\mathrm{N}$-acetylated chitosan and molecular weight dependence of its water solubility. Polymer J., 29:123127.

Kyan, T., M. Shintani, M. Sakurai, H. Ohashi, A. Fujisawa and S. Pongdit. (1999). Kyusei nature farming and the technology of effective microorganism. Atami (Japan), Asian Pacific Nat. Agric. Network.

Litchfield, J.T. and F.A. Wilcoxon (1949). A simplified method of evaluating dose - effect experiment. J. Pharm. Exp. Ther., 96:99-113.

Muthusamy, A. and N. Jayabalan (2011). In vitro induction of mutation in cotton Gossypium hirsutum L. and isolation of mutants with improved yield and fiber characters. Acta Physiol. Plantarum., 33 (5): 1793-1801.

Ndona, R. (2008). Influence of treatments with EMs Effective Microorganism on Tomato in protected cultivation. Thesis Univ. Nat. Res. and Life Sci., Vienna.

Nieuwenhuyse, P.V., P. Demaeght, W. Dermauw, M. Khalighi, C.V. Steven; B. Vanholme, L. Tirry; P.Lümmen and T. Van Leeuwen (2012). On the mode of action of bifenazate: New evidence for a mitochondrial target site, Pest. Biochem. and Physiol., 2 (104): 88-95.

Osman, M.S. (1997). Petroleum oils as a component of integrated pest management of phytophagous mites. Arab Gulf. J. Sci Entomol. Res., 15 (1): 125- 135.
Overmeer, W.P.J., M. Doode Man and A.Q. Van Zon (1982). Population and egg production in Amblyseius potentiallae and Typhodromus pyri (Acarina: Phytoseiidae). Z. Angew. Entomol., (93): 1-11.

Piraneo, T.G. (2013). Acaricide resistance of the two-spotted spider mite (Tetranychus urticae) in Pacific Northwest hops. M.Sc. Thesis, Washington State Univ.

Rabea, E.I., M.E.I. Badawy, C.V. Stevens; G. Smagghe and W. Steurbaut (2003). Chitosan as antimicrobial agent: Applications and mode of action. Biomacromolecules, 4: 1457 $-1465$.

Rahman, A.S., D. ukhopadhyaya, S.K. Brahmachary, R. L. Ulrichs and A. Goswami (2009). Surface functionalized amorphous nanosilica and microsilica with nanoporesas promising tools in biomedicine, Naturwissenschaften, 96: 31-38.

Riccardo, A., A. Muzzarelli, V. Stanic and V. Ramos (1998). Enzymatic depolymerization of chitins and chitosans methods in biotechnology, Carbohydrate Biotechnol. Protocols, 10.

Rouhani1, M., M.A. Samih and S. Kalantari (2008). Insecticidal effect of silica and silver nanoparticles on the cowpea seed beetle, Callosobruchus maculatus F. (Col.: Bruchidae) J. Ento. Res., Islamic Azad Univ.

Salem, I.E., A.A. El-Sheikh, E.A. Gomaa, W. M. Desuky and S.A. Raslan. (1995). Esterases and carbohydrate hydrolyzing enzymes determination in Spodoptera littoralis larvae treated with some IGRs. Zagazig J. Agric. Res., 22 (3): 901-906.

Salgado, V.L. (1997). The modes of action of spinosad and other insect products down to earth. Pest. Biochem. Physiol., 52 (1): 35-43.

Schmit, J.M. (1964). Kits for determination of serum total lipids concentration. Ph.D. Thesis, Lyon Univ., France, 121.

Siegel, M., R. Latch, G.C.M. Bush, L.P. Fannin, F.F. Rowan, D.D. Tapper, B.A. Bacon and M.C. Johnson (1990). Fungal entophyte infected grasses: alkaloid accumulation and aphid response. J. Chem. Ecol., 16: 3301-3316. 
Siegler, E.H. (1947). Leaf-disc technique for laboratory tests of acaricides. J. Econ. Entomol., (40): 441- 442.

Stone, D.B., J.H. Lynch, I. Kenneth and L.H. Stacy (2010). Exposure assessment: recommendations for nanotechnology-based pesticide Int. J. Occup. In vitro. Health., 16: 467-474.

Sun, Y.P. (1950). Toxicity index- an improved of comparing the relative toxicity of insecticides. J. Econ. Entomol., 43(1): 45-53.

Wigglesworth, V.B. (1959). Insect blood cells. Ann. Rev. Entomol., 4:1-16.

Wilkonson, C.F. (1976). Role of mixed function oxidases in insecticides resistance, in G.P; Georghiou and T. Saito (eds.) pest resistance to pesticides. Plenum, New York, $175-205$.

$\mathrm{Xu}$, H.L., R. Wang and M. Mridha (2000). Effects of organic fertilizers and a microbial inoculant on leaf photosynthesis and fruit yield and quality of tomato plants. J. Crop Prod., 3 (1): 173-182.
Younis, A.M., H.H. Hamouda, A.S. Ibrahim and M.A.Z. Zeitoun (2007). Field evaluation of certain pesticides against the cotton bollworms with special reference to their negative impact on beneficial arthropods. $8^{\text {th }}$ African Crop Sci. Soci. Conf., Elminia, Egypt., 27-31 October, 993-1002.

Zayed, M.S. (2016). Studies on the use of a safe alternatives against cotton bollworms. Ph.D. Thesis, Toxicol. And Chem. Pest., Kafr ElKheish Univ., 205.

Zhang, P.J., X.Y. Zhu, F. Huang, Y. Liu and J.M. Zhang (2011). Suppression of jasmonic acid-dependent defense in cotton plant by the mealy bug Phenacoccus solenopsis.

Zhu, F., Y. Cui, D.B. Walsh and L.C. Lavine (2014). Application of RNA Interference Toward Insecticide Resistance Management in Short Views on Insect. Biochem. and Molec. Biol., Int. Book Mission, Acad. Publisher, Manhattan, 2 (27): 595-619. 
Zagazig J. Agric. Res., Vol. 47 No. (4) 2020

تقييم الجسيمات النانوية الجديدة ضد العنكبوت الأحمر تتر انكس اورتيكا ومفترسه الأكاروسي

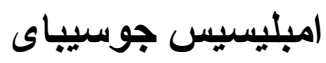

\author{
محمد سالم زايل \\ قسم المبيدات ـ كلية الزر اعة - جامعة دمباط ـ مصر مرابر
}

أجريت الدراسة الحالية لتقييم النشاط البيولوجي النسبي لستة مو اد، أربعة جسيمات نانوية (شيتوسان، هيدروكسي

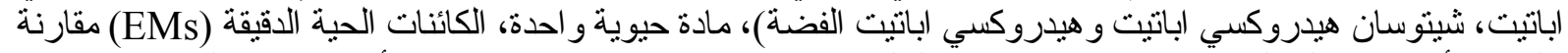

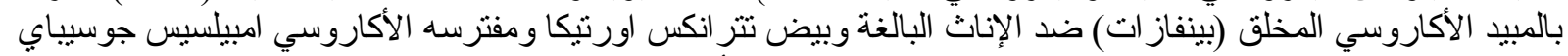

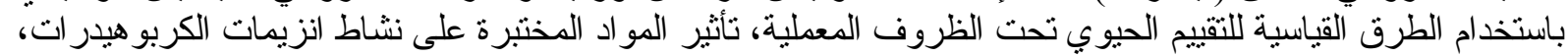

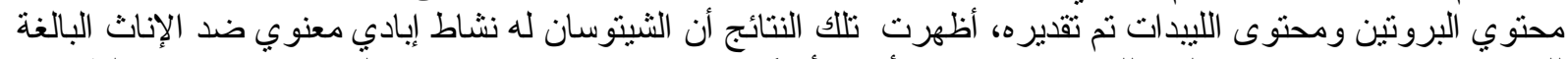

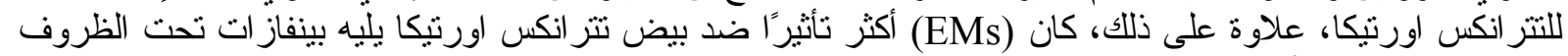

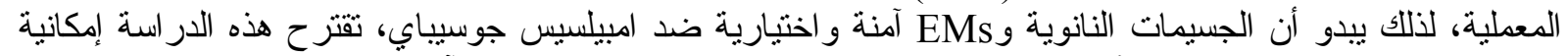

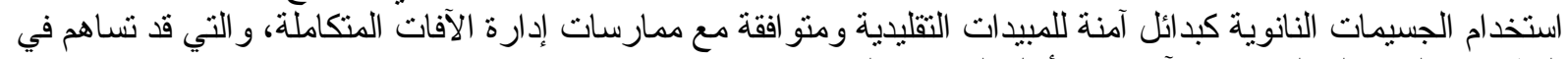

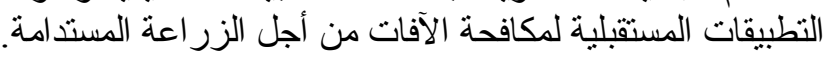

